\title{
PENGEMBANGAN DAYA TARIK OBJEK WISATA TELUK JERING KECAMATAN TAMBANG KABUPATEN KAMPAR
}

\author{
Roni Salambue'), Fatayat $^{2)}$, Evfi Mahdiyah ${ }^{3)}$, Yanti Andriyani ${ }^{4)}$ \\ 1, 2, 3,4) Program Studi Sistem Informasi FMIPA Universitas Riau Pekanbaru 28293 \\ E-mail: roni.salambue@lecturer.unri.ac.id
}

\begin{abstract}
ABSTRAK
Salah satu parawisata yang dapat menunjang perekonomian daerah yang terdapat di Kabupaten Kampar adalah Teluk Jering yang terdapat di Dusun III Desa Teluk Kenidai, Kecamatan Tambang, Kabupaten Kampar. Lokasi tersebut juga disebut dengan Pantai Cinta karena pasir yang ada di pinggir sungai tersebut memiliki pasir pantai yang putih dan bersih. Banyak warga yang berasal dari Pekanbaru dan daerah lainnya sengaja berkunjung ke Teluk Jering. Pengembangan dilakukan dengan pembuatan petunjuk jalan ke lokasi objek wisata, gapura, spot-spot foto, plang-plang informasi, website desa Teluk jering dan promosi dan publikasi di media sosial. Pengembangan dan objek wisata Teluk Jering akan berdampak pada kedatangan pengunjung ke objek wisata Teluk Jering akan meningkat penghasilan masyarakat Desa Teluk Jering. Sektor pariwisata merupakan sektor yang potensial untuk dikembangkan sebagai salah satu sumber pendapatan daerah. Perkembangan pariwisata tergantung kepada kunjungan yang datang mengunjungi tempat tersebut. Peningkatan jumlah kunjungan yang terjadi merupakan cermin dari terus berkembangnya kepariwisataan, untuk mempertahankan dan menambah jumlah kunjungan wisatawan.
\end{abstract}

Kata kunci: pengembangan, desa, wisata, teluk jering, pantai cinta

\section{ABSTRACT}

One tour that can support the regional economy found in Kampar Regency is Teluk Jering which is located in Dusun III in Teluk Kenidai Village, Tambang District, Kampar Regency. The location is also called Pantai Cinta because the sand on the edge of the river has white sand and clean beach. Many residents who came from Pekanbaru and other areas deliberately visited Teluk Jering. The development is carried out by making road directions to the location of attractions, gates, photo spots, information signs, the website of the Teluk Jering village and promotion and publication on social media. The development and tourism of Teluk Jering will have an impact on the arrival of visitors to the Teluk Jering tourist attraction will increase the income of the people of Teluk Jering Village. The tourism sector is a potential sector to be developed as a source of regional income. The development of tourism depends on the visits that come to visit the place. The increase in the number of visits that occur is a reflection of the continued development of tourism, to maintain and increase the number of tourist visits

Key words: development, village, tourism, teluk jering, pulau cinta 


\section{PENDAHULUAN}

Sektor pariwisata merupakan sektor yang potensial untuk dikembangkan sebagai salah satu sumber pendapatan daerah. Usaha memperbesar pendapatan asli daerah, maka program pengembangan dan pendayagunaan sumber daya dan potensi pariwisata daerah diharapkan dapat memberikan sumbangan bagi pembangunan ekonomi. Provinsi Riau memiliki berbagai kekayaan yaitu berupa kekayaan alam, seni dan budaya, hasil pertanian, bahasa, pulau, suku, flora, fauna, peninggalan purbakala, peninggalan sejarah, dan lain-lain. Berbagai kekayaan yang dimiliki Riau merupakan sumber daya dan modal yang besar artinya bagi usaha penanganan dan peningkatan kepariwisataan.

Kampar adalah salah satu Kabupaten di Riau yang memiliki potensi wisata yang besar, jika objek wisata di Kampar ini di perhatikan bukan tidak mungkin Kampar akan menjadi tujuan wisatawan dalam beberapa tahun ke depan. Masing-masing Kecamatan tersebut mempunyai objek wisata yang dapat dikembangkan. Berikut ini adalah data yang memperlihatkan bahwa tingkat kunjungan wisatawan ke Kabupaten Kampar terus meningkat dari tahun 2013 hingga tahun 2017.

Tabel 1. Data kunjungan ke Kabupaten Kampar

\begin{tabular}{rcc}
\hline No. & Tahun & Jumlah (Orang) \\
\hline 1. & 2013 & 35.434 \\
\hline 2. & 2014 & 39.543 \\
\hline 3. & 2015 & 59.639 \\
\hline 4. & 2016 & 65.853 \\
\hline 5. & 2017 & 86.598
\end{tabular}

Sumber: Data Dinas Pariwisata, Pemuda Dan Olahraga Kabupaten Kampar

Menurut data dari Kepala Dinas Pariwisata dan Kebudayaan Kampar, Zulia Dharma, tempat ini telah dikunjungi sebanyak 300.695 pelajar/mahasiswa, 402.099 wisatawan nusantara dan 69 wisatawan mancanegara sejak Januari sampai Agustus 2018. Zulia mengungkapkan Teluk Jering adalah pengunjung yang terbanyak dari seluruh objek wisata lain di Kampar (Sumber: Pekanbaru Tribun News 28/10/2018).

Selain panorama yang indah, di Teluk Jering ini juga terdapat fasilitas banana boat, donut boat, speed boat, dan kapal hias. Wisatawan juga bisa berfoto di spot-spot foto yang telah disediakan, namun spot foto yang disediakan terbatas dan berbayar sehingga wisatawan perlu mengeluarkan uang lebih. Spot-spot foto yang minim, keindahan dan kebersihan, serta kondisi jalan menuju ke objek wisata adalah hal-hal yang masih perlu dibenahi.

Salah satu parawisata yang dapat menunjang perekonomian daerah yang terdapat di Kabupaten Kampar adalah Teluk Jering Teluk Jering yang terdapat di Dusun III Desa Teluk Kenidai, Kecamatan Tambang, Kabupaten Kampar. Lokasi tersebut juga disebut dengan Teluk Jering atau Pantai Cinta karena pasir yang ada di pinggir sungai tersebut memiliki pasir pantai yang putih dan bersih. Banyak warga yang berasal dari Pekanbaru dan daerah lainnya sengaja berkunjung ke Teluk Jering

Untuk sampai ke Wisata Teluk Jering atau Teluk Jering dapat ditempuh dengan kendaraan roda 4 dan roda 2 kurang lebih 40 menit dari Pekanbaru, tidak jauh dari jembatan Sungai Kampar yang ada di Teratak Buluh. Sekitar 1,5 km dari jembatan panjang Sungai Kampar, lalu belok ke kanan masuk ke jalan tanah dan kondisi jalannya memiliki beberapa kerusakan. Kita harus menempuh kurang lebih $2 \mathrm{~km}$ lagi atau 15 menit untuk sampai ke Wisata Teluk Jering atau Teluk Jering.

Perkembangan pariwisata tergantung kepada kunjungan yang datang mengunjungi tempat tersebut. Peningkatan jumlah kunjungan yang terjadi merupakan 
cermin dari terus berkembangnya kepariwisataan, untuk mempertahankan dan menambah jumlah kunjungan wisatawan pada tahun berikutnya, hal tersebut tidak terlepas dari pentingnya faktor kenyamanan dan keamanan (Kumala, Borman, \& Prasetyawan, 2018).

Untuk mempertahankan jumlah kunjungan dengan tercapainya target yang di inginkan dalam suatu objek wisata, maka diperlukan pengelolaan dan pengembangan objek wisata. Pengelolaan dan pengembangan dapat dilakukan dengan menentukan faktor yang akan menjadi peran penting dan pendukung untuk mengembangkan pengunjung mengunjungi objek wisata Teluk Jering. Lebih lanjut Yoeti (2008) mengungkapkan bahwa terdapat beberapa hal yang perlu diperhatikan dalam pengembangan suatu objek wisata, yaitu:

1. Objek wisata itu harus mempunyai sesuatu yang menarik untuk dilihat dan tentunya berbeda dengan yang dimiliki tempat lain (something to see).

2. Dilokasi objek wisata harus tersedia kegiatan yang dapat dilakukan oleh visitor (fishing, tracking, dll).

3. Dilokasi objek wisata harus tersedia dengan apa yang disebut something to buy.

Pengembangan objek wisata merupakan suatu hal yang besar karena melingkupi banyak pihak, biaya, pemikiran, partisipasi dari warga setempat, pemerintah dan investor yang berminat. Pengembangan daya tarik wisata sendiri memiliki tujuan untuk berkembang kearah yang lebih baik yang akhirnya dapat menghasilkan manfaat yang dapat dirasakan oleh banyak orang disamping untuk konservasi objek wisata itu sendiri. Adapun tujuan pelaksanaan kegiatan ini adalah sebagai berikut:

1. Mengembangkan obyek wisata Teluk Jering mudah dicari oleh pengunjung

2. Membuat spot untuk lokasi foto di lokasi wisata yang menjadi daya tarik bagi pengunjung lokasi wisata

3. Melakukan promosi dan sosialisasi obyek wisata Teluk Jering kepada masyarakat menggunakan media sosial dan media online.

\section{TINJAUAN PUSTAKA}

Pariwisata merupakan suatu keseluruhan elemen-elemen terkait yang didalamnya terdiri dari wisatawan, daerah tujuan wisata, perjalanan, industri dan lain sebagainya yang merupakan kegiatan pariwisata (Devy and Soemanto, 2017). Pariwisata menjadi andalan utama sumber devisa karena Indonesia merupakan salah satu Negara yang memiliki beraneka ragam jenis pariwisata, seperti wisata alam, sosial maupun wisata. Pengembangan objek membutuhkan kerjasama seluruh pemangku kepentingan yang terdiri dari masyarakat dan pemerintah. Sesuai dengan tugas dan kewenangannya, pemerintah merupakan pihak fasilitator yang memiliki peran dan fungsinya dalam pembuatan dan penentu seluruh kebijakan terkait pengembangan objek dan daya tarik wisata. Daya tarik dalam objek wisata merupakan salah satu modal utama yang harus dimiliki dalam upaya peningkatan dan pengembangan objek wisata, hal ini disebabkan karena faktor utama yang membuat pengunjung atau wisatawan untuk mengunjungi daerah tujuan wisata adalah potensi dan daya tarik yang dimiliki obyek wisata tersebut.

Beberapa faktor yang dipertimbangkan dalam pengembangan objek wisata adalah (Mario Barreto, 2015):

1. Kualitas objek wisata yaitu bagaimana untuk mengupayakan dan menjaga kelestarian alam 
2. Keunikan agar banyak pengunjung dapat rekreasi.

3. Promosi melalui media sosial (instagram), youtube dan website

4. Sumber daya manusia yang menjaga kelestarian objek wisata

5. Inovasi objek wisata yakni bagaimana untuk melestarikan objek wisata yang baik

Supaya obyek wisata ini dapat dikenal maka perlu dilakukan promosi. Promosi dapat dilakukan menggunakan media online yaitu website, media sosial instagram dan youtube. Penggunaan website sebagai media promosi dilakukan dengan mengintegrasikan dengan website dinas pariwisata. Informasi yang disajikan adalah tempat-tempat wisata dan kegiatan-kegiatan pariwisata (Abidi and Ramadhani, 2012). Media sosial seperti instagram juga sudah digunakan sebagai media promosi. Hal ini karena masifnya penggunaan smartphone dan kemudahan untuk mengakses media internet. Instagram merupakan media jejaring sosial yang memiliki fitur-fitur yang mendukung untuk melakukan kegiatan pariwisata (Agus Purnomo, 2018). Alasannya adalah instagram merupakan media jejaring sosial berbasis foto dan video. Pengguna instagram di Indonesia saat ini berkisar 22 juta orang, sehingga media ini sesuai sekali digunakan sebagai media promosi. Selain instagram, promosi dapat juga digunakan dengan youtube yang merupakan situs berbagi video yang disediakan oleh google. Penggunaan YouTube dalam mempromosikan objek wisata sangat bergantung bagaiamana video yang diupload, durasi, pengambilan gambar, backsound, dan scene kawasan objek wisata (Amin, 2016).

\section{METODE PELAKSANAAN}

Pembangunan desa selama ini masih sering menganut konsep "membangun desa" dan bukan "desa membangun". Pada konsep membangun desa, faktor eksternal lebih berperan menentukan arah pembangunan desa dan ini menyebabkan desa semakin tergantung pada bantuan luar. Sebaliknya, pada konsep desa membangun peran masyarakat justruu menjadi faktor utama guna membangun desa yang berketahanan.

Dalam konteks pariwisata, besarnya peranan pihak luar sering mengarah bukan pada kebutuhan masyarakat desa. Untuk kepentingan nasional, pembangunan pariwisata perdesaan sering diarahkan pada konsep keserakahan dengan tujuan untuk mendatangkan jumlah wisatawan sebanyak-banyaknya. Sebaliknya, pembangunan bersama masyarakat akan menyebabkan pembangunan pariwisata mengarah pada potensi objek wisata karena berkaitan dengan kepentingan jangka panjang masyarakat itu sendiri.

Pembangunan potensi objek wisata dengan salah satunya mendirikan spot foto yang menarik juga mengarah pada upaya untuk mengoptimalkan jumlah pariwisata atau pengunjung di Teluk Jering. Besarnya jumlah pengunjung yang datang tentunya akan membantu perekonomian masyarakat, karena mata pencarian masyarakat desa sebagian besar adalah berdagang di lokasi objek wisata.

Program-program yang ada terdiri dari tiga macam yaitu:

1. Program awal

2. Program inti

3. Program akhir 
Program awal adalah program yang direncanakan untuk memperoleh dukungan masyarakat setempat, berupa sosialisasi dan kunjungan, sosialisasi ini dilakukan kepada masyarakat untuk menyampaikan maksud dan tujuan kegiatan di desa mereka, serta meminta bantuan kepada pemuda setempat agar sekiranya dapat membantu jika terjadi kendala dalam pembuatan program kerja yang telah disusun.

Program inti adalah program yang direncanakan dan dalam pelaksanaanya sesuai dengan potensi yang bisa dikembangkan ditempat wisata tersebut, adapun program ini berupa program-program pembuatan spot-spot foto, yang bertujuan sebagai daya tarik objek wisata, memperbaiki serta memperindah fasilitas yang sudah ada. Diantaranya pembuatan spot foto You \& Me, taman angka, taman mini dari ban bekas, gembok cinta, papan milenial, spot berbentuk hati, memperindah pondok milik warga dengan mengecatnya serta menambah jumlah tong sampah yang berguna sebagai penunjang fasilitas di objek wisata tersebut. Pelaksanaan program ini dilakukan dalam target-target dan tahapan yang rencanakan agar dalam pengerjaannya lebih teratur dan selesai sesuai dengan waktu yang telah ditetapkan dengan timeline yang sudah dijadwalkan.

Selanjutnya program akhir adalah program yang direncanakan dan dilaksanakan sebagai salah satu bentuk silaturrahmi dengan masyarakat desa tersebut. Dikatakan program akhir karena dalam tahap pelaksanaannya adalah yang paling akhir dilaksanakan. Program ini berupa bentuk silaturahmi dengan masyarakat di dusun lain yang ada di desa Teluk Kenidai tersebut. Sekaligus mengingformasikan kepada masyarakat dusun lain dengan program kerja yang ada agar masyarakat dusun lain paham jika kegiatan yang dilakukan harus sesuai dengan waktunya dan memberi manfaat terhadap desa mereka.

Secara ringkas, komponen pembangunan utama untuk pengembangan potensi objek wisata Teluk Jering adalah sebagai berikut:

Tabel 2. Pengembangan potensi objek wisata Teluk Jering

\begin{tabular}{|c|c|}
\hline $\begin{array}{l}\text { Perbaikan Fasilitas Objek } \\
\text { Wisata Teluk Jering }\end{array}$ & Sosialisasi Sadar Wisata \\
\hline $\begin{array}{l}\text { - Peningkatan penyediaan } \\
\text { fasilitas umum dasar; } \\
\text { - Pembangunan fisik daya } \\
\text { tarik wisata; } \\
\text { - Pembangunan } \\
\text { infrastruktur pendukung; } \\
\text { - Peningkatan sumber daya } \\
\text { manusia pengelola dan } \\
\text { pelaku usaha (masyarakat } \\
\text { desa); }\end{array}$ & 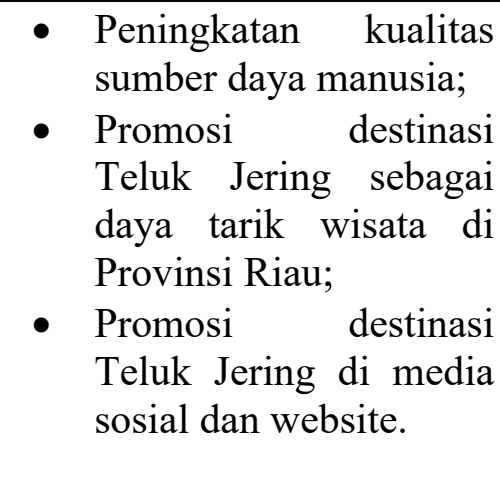 \\
\hline
\end{tabular}

\section{HASIL DAN PEMBAHASAN}

\section{Potensi Pengembangan Masyarakat}

Pengembangan obyek wisata ini dilakukan agar meningkatnya daya tarik masyarakat terhadap fasilitas wisata di Pulau Cinta. Beberapa manfaat yang dihasilkan dari pengembangan ini adalah:

1. Meningkatnya kesejahteraan ekonomi dan sosial masyarakat melalui pendayagunaan sumber daya lokal. 
2. Melestarikan dan mempromosikan warisan budaya bagi kesejahteraan masyarakat

3. Memberikan kesejahteraan masyarakat dalam arti luas, termasuk kepuasan dan kebahagiaan masyarakat.

4. Mendorong kunjungan wisatawan yang bermanfaat bagi lingkungan dan masyarakat lokal, dan bukan sebaliknya

5. Mendorong konsep keseimbangan kepuasan wisatawan dan kepuasan komunitas untuk menghindari terjadinya iritasi sosial di masyarakat lokal.

6. Meningkatkan partisipasi masyarakat dalam pembangunan (prinsip pembangunan pariwisata berbasis komunitas).

\section{Solusi Pengembangan Masyarakat}

Tahapan kegiatan yang dilakukan untuk mendapatkan manfaat yang dicanangkan dalam dalam pengembangan ini adalah:

1. Sosialisasi dengan Ketua Pokdarwis

Kegiatan ini merupakan bentuk pertemuan antara tim pelaksana dan ketua Pokdarwis berserta perangkat desa. Sosialisasi ini membahas tentang program kegiatan dari tim pelaksana, mendengarkan paparan tentang roadmap pengembangan obyek wisata Pulau Cinta.

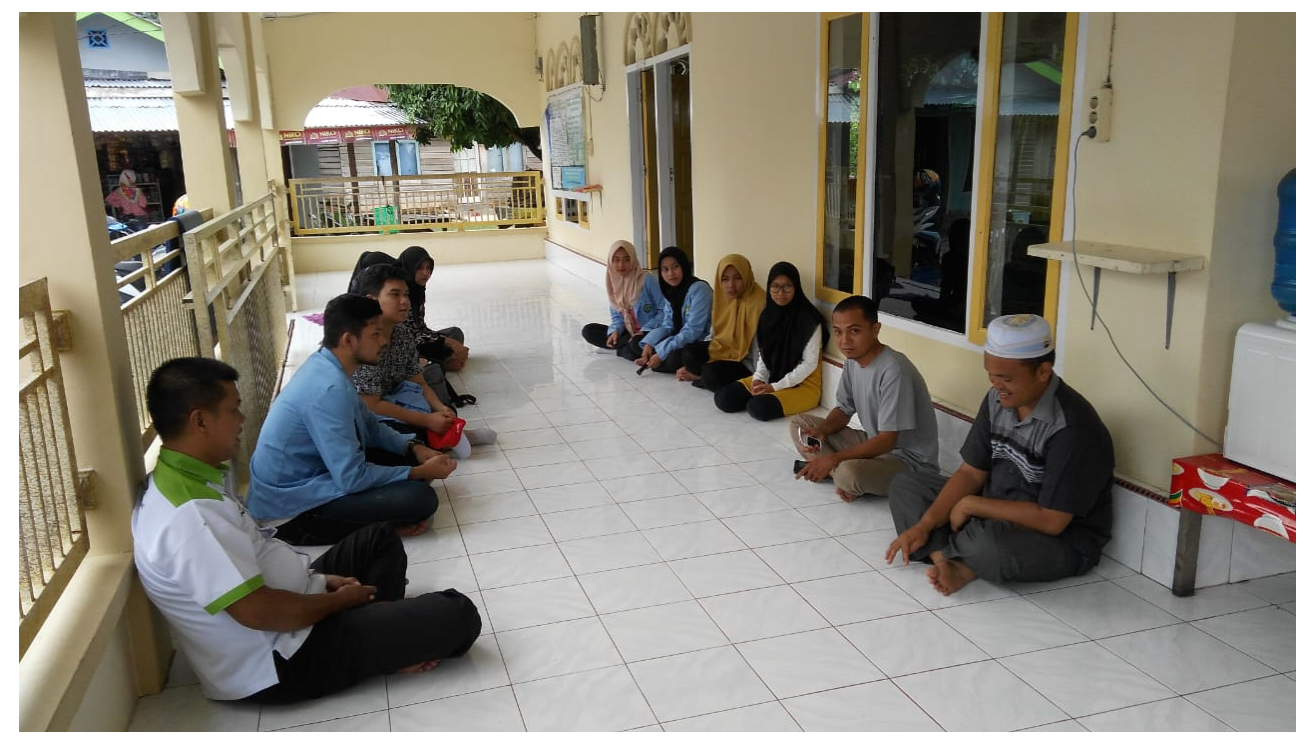

Gambar 1. Sosialisasi tim pelaksana dengan Pokdarwis

2. Menentukan Lokasi Pembuatan Spot Foto

Setelah dilakukan sosialisasi yang membahas program kerja maka tahapan selanjutnya adalah menentukan lokasi yang tepat untuk membuat spot foto. Lokasi yang dipilih haruslah strategis dan membuat pengunjung tertarik untuk mengabadikan moment liburannya. Diskusi yang dilakukan dengan ketua pokdarwis menghasilkan kesepakatan bahwa lokasi yang tepat adalah padang rumput tepi aliran anak sungai.lokasi ini dianggap tepat karena mampu menciptakan suatu objek yang baru dan menarik terutama saat senja dengan matahari tenggelam yang indah. 
3. Pengadaan Alat dan Bahan

Proses pembelian bahan dilakukan beberapa tahap karena menyesuaikan dengan pekerjaan yang sedang dilakukan. Pembelian harus sesuai dengan alat dan bahan yang dibutuhkan agar tidak boros dan tepat guna. Mengingat akan biaya yang diperlukan tidaklah murah membuat tahapan ini menjadi sangat penting.

Pembelian alat dan bahan membutuhkan alat transportasi seperti pick up karena beberapa alat tidak dapat dibawa menggunakan sepeda motor, contohnya yaitu kayu balok, papan, triplek, bambu, ember cat bekas, ban bekas dan sebagainya.

4. Memperindah Fasilitas yang Sudah Ada

Tulisan Pulau Cinta ini merupakan salah satu aset yang dimiliki Obyek Wisata Teluk Jering dalam mempromosikan wisatanya. Bagaimana tidak, setiap pengunjung yang datang pasti menyempatkan diri untuk foto bersama tulisan Pulau Cinta sebagai memories kalau ia pernah berkunjung kemari. Tentunya melihat sebegitu potensialnya Tulisan Pulau Cinta ini dalam menarik minat pengunjung untuk menjadikannya spot foto, maka tim kukerta integrasi berinisiatif untuk mengambil tindakan memperbaiki kembali dan mengecat ulang

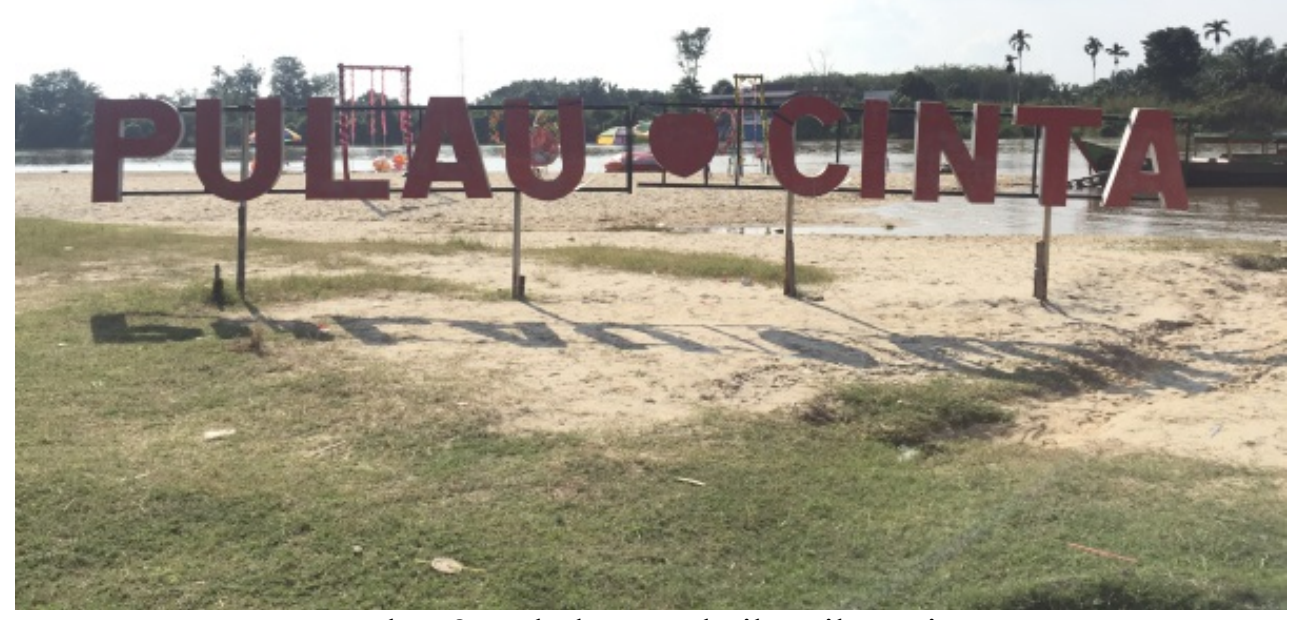

Gambar 2. Sebelum perbaikan ikon cinta 


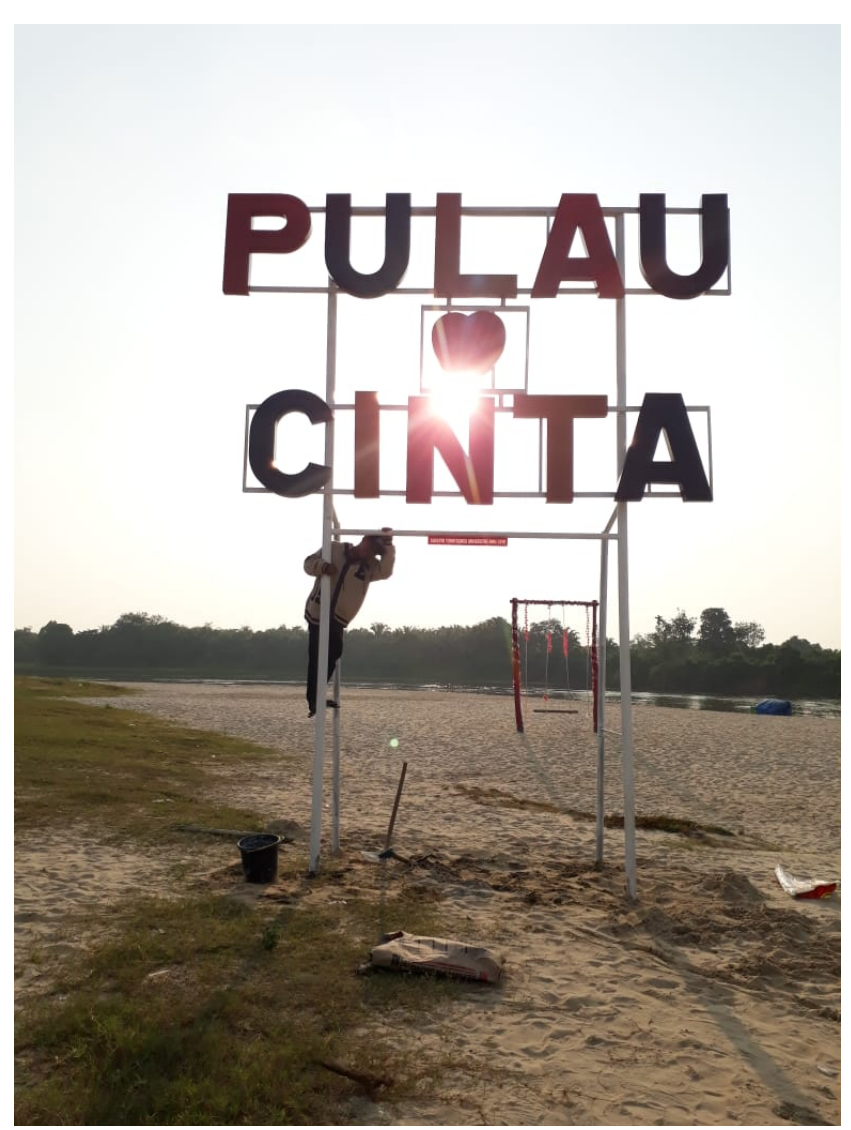

Gambar 3. Setelah perbaikan ikon pulau cinta

5. Membuat Spot Foto

Salah satu spot foto yang dirancang adalah membuat ukiran tulisan "You and Me". Tulisan tersebut diharapkan dapat mengundang kaum milenial untuk menyemarakkan foto di spot foto tersebut. pada kesempatan ini segmentasinya ada pada kawula muda untuk memperkenalkan obyek wisata Teluk Jering lebih luas lagi.

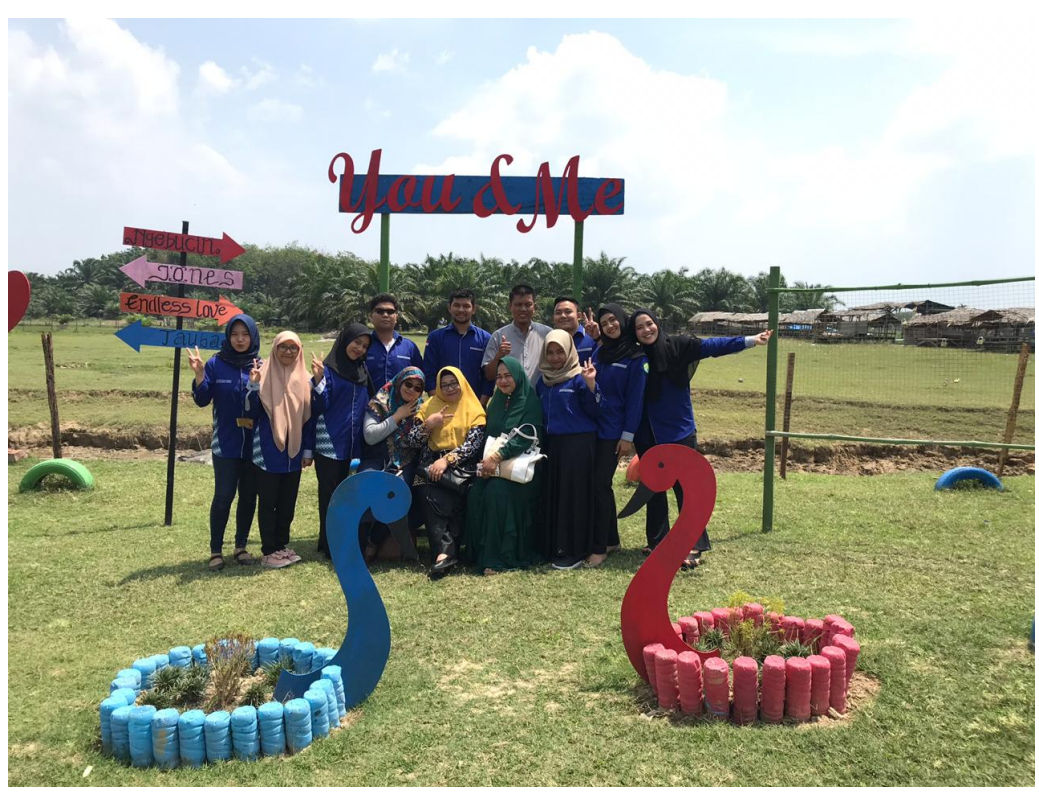

Gambar 4. Spot foto YOU \& ME 
6. Membuat Tong Sampah

Pembuatan tong sampah dilakukan untuk menertibkan pengunjung agar membuang sampah pada tempatnya. Tong sampah dibuat dari barang bekas, yakni dari kaleng cat bekas yang dilukis dan diwarnai semenarik mungkin. Selain di lukis dan diwarnai, terdapat kata kata imbauan untuk menjaga kebersihan serta ketertiban lingkungan pada tong sampah tersebut. Lima belas tong sampah yang dibuat dan didistribusikan secara merata pada setiap pondok.

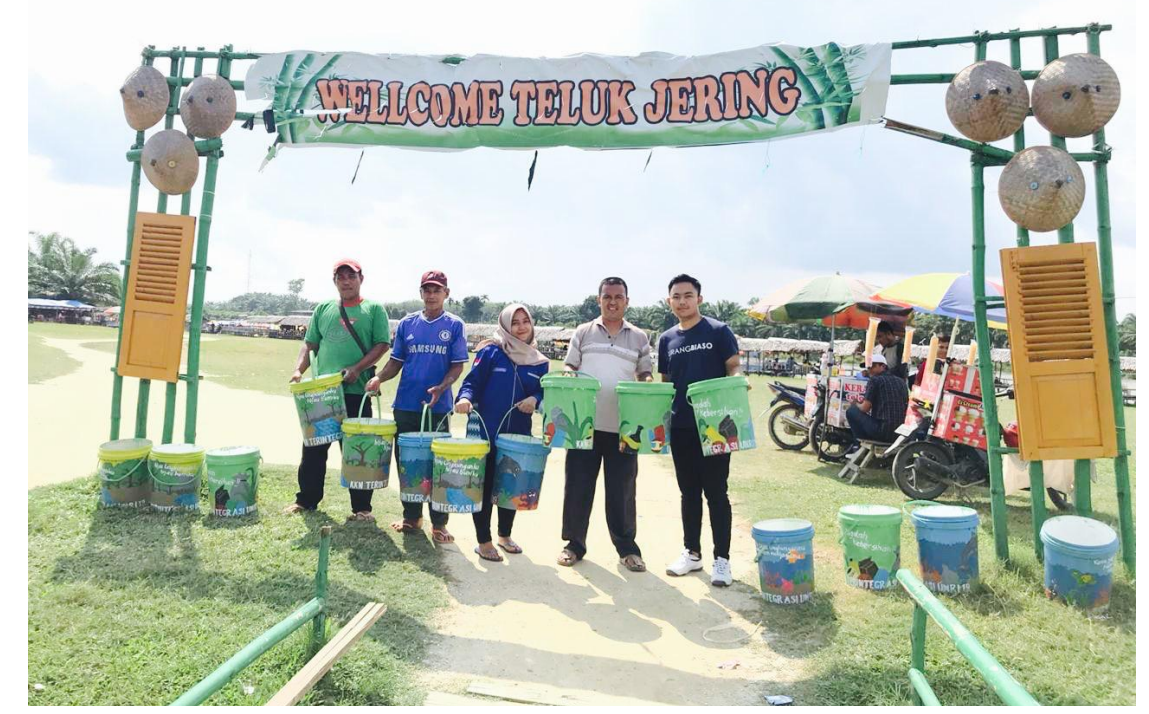

Gambar 5. Pembuatan tong sampah

\section{KESIMPULAN}

Kesimpulan yang diambil dari pelaksanaan kegiatan ini adalah sebagai berikut:

1. Pengembangan obyek wisata Pulau Cinta harus didukung dengan perencanaan yang baik dan dana yang besar.

2. Obyek wisata Pulau Cinta mempunyai beberapa spot tambahan yang dibuat berdasarkan konsep cinta sesuai dengan nama obyek wisatanya.

3. Spot yang ada di Pulau Cinta dapat menarik wisatawan berkunjung ke Pulau Cinta.

\section{DAFTAR PUSTAKA}

[1]. Abidi, F. and Ramadhani, N. (2012) 'Perancangan Website Promosi Wisata Jawa Timur dengan Konsep the Guide to the Bold Diversity', Jurnal Teknik POMITS, 13(13), pp. 1-5.

[2]. Agus Purnomo (2018) Pemanfaatan Instagram Sebagai Media Komunikasi Pariwisata di Kabupaten Karanganyar (Studi Analisis Deskriptif Kualitatif Pada Akun Instagram@Explorekabkaranganyar). Universitas Muhammadiyah Surakarta.

[3]. Amin, M. R. (2016) Penggunaan YouTube Sebagai Media Promosi Kawasan Wisata Mandeh di Kabupaten Pesisir Selatan. Universitas Andalas.

[4]. BPS Kampar (2018) 'Kecamatan Kampar Kiri Dalam Angka 2018', Badan Pusat Statistik Kabupaten Kampar, 91, pp. 399-404. 
[5]. Desa Teluk Kenidai (2018) 'Monografi Desa Teluk Kenidai'.

[6]. Devy, H. and Soemanto, R. B. (2017) 'Pengembangan Obyek Dan Daya Tarik Wisata Alam Sebagai Daerah Tujuan Wisata Di Kabupaten Karanganyar', Jurnal Sosiologi DILEMA, 32(1), pp. 34-44.

[7]. Mario Barreto, I. G. A. K. G. (2015) 'Strategi Pengembangan Objek Wisata Air Panas di Desa Marobo, Kabupaten Bobonaro, Timor Leste', E-Jurnal Ekonomi dan Bisnis Universitas Udayana, 5(4), pp. 2637-2664.

[8]. Sihombing, F. and Harismanto (2018) 'Pulau Cinta Teluk Jering Primadona Baru Wisata Riau', Tribun News. Available at: https://pekanbaru.tribunnews.com/2018/10/28/pulau-cinta-teluk-jeringprimadona-baru-wisata-riau. 